\title{
Independent marine and atmospheric model estimates of the sea- air flux of dimethylsulfide in the Southern Ocean
}

\author{
Albert J. Gabric', Gregory P. Ayers ${ }^{2}$, and Graham C. Sander ${ }^{3}$
}

\begin{abstract}
Marine and atmospheric models have been combined with data collected at the Cape Grim atmospheric baseline station, to estimate the flux of dimethylsulfide to the atmosphere during the spring-summer period in the Subantarctic Southern Ocean in the vicinity of the Cape Grim baseline atmospheric monitoring station. The marine model predicts that production of phytoplankton and of dissolved DMS will increase during spring to reach a maximum in summer consistent with the data on atmospheric DMS. Local wind and sea temperature data have been used to calculate the DMS transfer velocity which was used to compute the sea-to-air flux of DMS. Independent predictions of the DMS flux using an atmospheric model and Cape Grim data are in excellent agreement with the marine based prediction.
\end{abstract}

\section{Introduction}

Dimethylsulfide (DMS; $\mathrm{CH}_{3} \mathrm{SCH}_{3}$ ) is an important sulfurcontaining trace gas produced by some classes of marine phytoplankton [Keller et al., 1989; Turner et al., 1988; Iverson et al., 1989]. Charlson et al. [1987] have suggested that a major source of cloud condensation nuclei $(\mathrm{CCN})$ over the oceans is the DMS produced by planktonic algae in seawater. DMS is oxidised in the atmosphere to form non-sea-salt sulfate (n.s.s $\mathrm{SO}_{4}{ }^{2-}$ ) and methanesulfonate (MSA) aerosols. Because the formation of clouds is sensitive to CCN density, it has been postulated that biological regulation of the climate is possible by affecting albedo and thus the Earth's radiation budget.

The Southern Ocean is relatively unpolluted and thus the production of sulphate aerosols will be mainly due to the biogenic source of DMS. Measurements made at Cape Grim, Tasmania $\left(40^{\circ} 41^{\prime} \mathrm{S}, 144^{\circ} 41^{\prime} \mathrm{E}\right)$ by Ayers et al. [1991] have confirmed the connection between atmospheric DMS and aerosol sulphur species. A pronounced seasonal cycle in atmospheric DMS concentration was detected, with an amplitude of between 10 and 20 from a January maximum to August minimum. A similar cycle in MSA and n.s.s sulphate was also evident suggesting a tight coupling between DMS, MSA and n.s.s. sulphate aerosols.

DMS measurements at Cape Grim will be affected by DMS production is a large oceanic region upwind. The extent of this region depends on wind strength, and the lifetime of gaseous DMS in the marine boundary layer. Wind speeds vary from a monthly mean value of $11 \mathrm{~ms}^{-1}$ in January to $7 \mathrm{~ms}^{-1}$ in June, thus an air parcel can travel up to $1000 \mathrm{~km}$ per day [Wilson and Ayers, 1990]. Since the lifetime of gaseous DMS varies from

\footnotetext{
'Feculty of Environmental Sciences, Griffith University, Nathan, Queenalend, Australia.

${ }^{2}$ CSIRO Division of Atmospheric Research, Mordialloc, Victoria, Australia.

${ }^{3}$ Feculty of Science and Technology, Griffith University, Nathan, Queonsland, Australia.
}

Copyright 1995 by the American Geophysical Union.

Paper number 95GL02936

0094-8534/95/95GL-02936\$03.00 approximately half a day in summer to about a week in winter [Koga and Tanaka, 1993], the atmospheric DMS concentrations observed at Cape Grim may reflect oceanic production in a quadrant well over $1000 \mathrm{~km}$ west and south of Cape Grim. While there are few measurements of aqueous DMS in the ocean southwest of Cape Grim, northern hemisphere data [Bates et al. 1987; Turner et al. 1988; Leck et al. 1990; Nguyen et al. 1990] show that average surface seawater DMS concentration may display a seasonal variation of up to a factor of 50 in mid and high latitudes, from a typical winter value of $0.2 \mathrm{nM}$ to a summer maximum of $10 \mathrm{nM}$. Measurements made by McTaggart and Burton [1992] in the Southern Ocean between $40-53^{\circ} \mathrm{S}$ during the 1988-89 austral summer recorded mean January DMS of 20.5 $\mathrm{nM}$, a very high value compared to the global mean concentration of about 3nM [Andreae and Barnard, 1984] or the value of $6.8 \mathrm{nM}$ found by Turner et al. [1988] in the North Sea during the summer of 1985 .

Here we present results from the modelling of both the marine and atmospheric phases of DMS and derive independent estimates of the sea-to-air DMS flux under conditions typical of the Subantarctic Southern Ocean. A longer term aim is to develop a tool that can be used to test the feedback on DMS production in the Southern Ocean of various climate change scenarios [eg Pittock, 1993]. Lawrence [1993] used a much simpler empirical model to suggest that the climate feedback of the DMS cycle could indeed be significant.

\section{Model structure and assumptions}

\section{The Marine Phase}

The marine DMS production model (henceforth referred to as the GMSK model) has been described in Gabric et al. [1993]. The model structure reflects the current ecological paradigm with micro-organisms playing a central role in elemental recycling [Azam et al., 1983; Fenchel, 1988] and also controlling DMS turnover in the water column [Kiene and Bates, 1990]. The model is time-dependent with state variables vertically averaged over the mixed layer. The biotic compartments comprise a generic autotroph (phytoplankton), planktonic bacteria which metabolise DMS and its precursor dimethylsulfonium propionate (DMSP), and three heterotrophs. For simplicity, no higher trophic levels are considered although zooplankton export through grazing by fish is included.

Predictions suggest that the DMS concentration and hence flux to the atmosphere will depend on the stage of the phytoplankton bloom. This has recently been confirmed in field experiments done by Matrai and Keller [1993]. Simpler steadystate models like that of Lawrence [1993], which assume a linear relationship between DMS concentration and phytoplankton population density, may underestimate the total DMS produced after the phytoplankton bloom has declined and consequently the overall strength of any climate feedback. In order to adapt the GMSK model to the Southern Ocean, the DMS transfer velocity has been parameterised in terms of wind speed and ocean temperature. The wind speed $(w)$ dependence of the transfer 
(a)

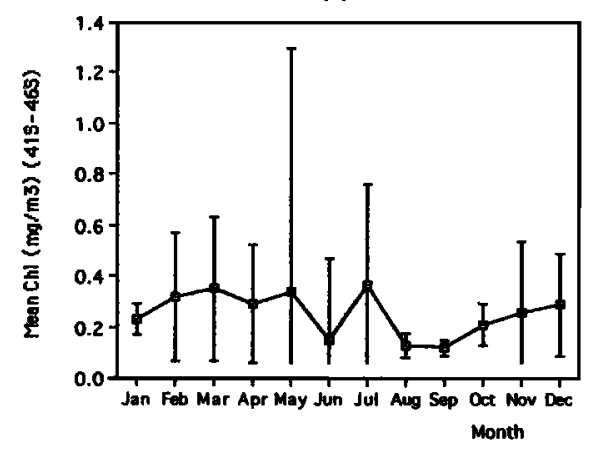

velocity $\mathrm{k}_{\mathrm{w}}\left(\mathrm{cm} \mathrm{h}^{-1}\right)$ was calculated from the equations given by Liss and Merlivat [1986] which were derived for $\mathrm{CO}_{2}$ at $20^{\circ} \mathrm{C}$ and a Schmidt number (Sc) of 600,

$$
\begin{aligned}
& k_{w}=0.17 w \quad \text { for } w \leq 3.6 \\
& k_{w}=2.85 w-9.65 \text { for } 3.6<w \leq 13 \\
& k_{w}=5.9 w-49.3 \quad \text { for } w>13
\end{aligned}
$$

These equations must be rescaled to apply for DMS and different Sc. Liss and Merlivat assume that $\mathbf{k}_{\mathbf{w}}$ is proportional to $\mathrm{Sc}^{-2 / 3}$, for wind speeds less than $3.6 \mathrm{~ms}^{-1}$, and Sc$-1 / 2$ for higher wind speeds. Rescaling equations (1) and enforcing piecewise continuity at the wind speed boundaries gives,

$$
\begin{aligned}
& k_{w}=0.17 \alpha w \quad \text { for } w \leq 3.6 \\
& k_{w}=\beta(2.85 w-10.26)+0.612 \alpha \quad \text { for } 3.6<w \leq 13 \\
& k_{w}=\beta(5.9 w-49.91)+0.612 \alpha \quad \text { for } w>13
\end{aligned}
$$

with $\alpha=(600 / \mathrm{Sc})^{2 / 3}$ and $\beta=(600 / \mathrm{Sc})^{1 / 2}$. For a given gas, $\mathrm{Sc}$ varies with water temperature, decreasing as the temperature increases. The dependence of Sc on sea surface temperature (SST) for DMS was presented graphically by Erickson et al. [1990] and a cubic polynomial has been fitted to that data for use in the model,

$$
S c=3628.5-234.58(S S T)+7.8601(S S T)^{2}-0.1148(S S T)^{3}
$$

Sea surface temperature south-west of Cape Grim has been modelled as a periodic function with a period of one year,

$$
\begin{aligned}
S S T= & 0.5\left\{\left(S S T_{\max }+S S T_{\min }\right)\right. \\
& \left.+\left(S S T_{\max }-S S T_{\min }\right) \cos \left[\left(t-t_{m}\right) \pi / 180\right]\right\}
\end{aligned}
$$

where $\mathrm{SST}_{\max }$ and $\mathrm{SST}_{\min }$ are the maximum and minimum annual temperatures, $t$ the time in Julian days and $t_{m}$ the Julian day on which the maximum temperature occurs. The maximum and minimum sea surface temperatures are estimated to be $14.6^{\circ} \mathrm{C}$ and $9.4^{\circ} \mathrm{C}$, respectively, with the maximum occurring on Julian day 17.

The GMSK model formulation of phytoplankton specific growth rate has been extended to include the dual effects of light and ambient temperature - the so-called multiplicative growth model [ Platt et al., 1977],

$$
\mu=V_{N} R_{L} R_{T}
$$

where $V_{N}\left(h^{-1}\right)$ is the nitrogen-specific nutrient uptake rate following the Michaelis-Menten form given in the original GMSK formulation, and $R_{L}$ and $R_{T}$ are dimensionless light and temperature limitation coefficients, respectively.

Field measurements suggest dissolved nitrate levels in the Subantarctic Southern Ocean are very high in late winter, typically $11.5 \mu \mathrm{M}$, and drop to $2.1 \mu \mathrm{M}$ by the end of the austral summer [J.Parslow, pers. comm.]. The half-saturation concentration $\mathrm{K}_{\mathrm{s}}$ for nitrate vary with algal species size and (b)

Figure 1. Monthly average pigment concentration and standard deviations as derived from CZCS 1978-86 composited data (a) $41^{\circ}-46^{\circ} \mathrm{S}$,

(b) $46^{\circ}-51^{\circ} \mathrm{S}$ ambient nutrient status, however oceanic species tend to have values in the range 0.1 to $1.0 \mu \mathrm{M}$ [Parsons et al., 1986], suggesting that in this region nitrate limitation is unlikely to occur.

A radiation model [Brock, 1981] has been calibrated with meteorological data on cloudiness and surface solar radiation collected at Cape Grim and used to compute the incident total solar irradiance at the sea surface, $I_{s}$. Irradiance in the photosynthetically active range $350-700 \mathrm{~nm}$ (PAR), has been estimated by Baker and Frouin [1987] to be in the range $0.42 \mathrm{I}_{s}$ to $0.48 \mathrm{I}_{\mathrm{s}}$ for mid to high latitudes under clear skies. The ratio of PAR to total irradiance is expected to increase under cloudy skies so the constant value of 0.45 [Jerlov, 1976; Jitts et al., 1976] which has been used here would be a lower bound on the true PAR.

In the Subantarctic ocean the mixed layer depth varies seasonally from about $100 \mathrm{~m}$ in summer to about $500 \mathrm{~m}$ in winter [J. Parslow, pers. comm.]. The euphotic zone depth is fairly constant at around $90 \mathrm{~m}$ for the whole year. Assuming that light is exponentially attenuated with depth, and that the irradiance at the bottom of euphotic zone $\left(z=Z_{e}\right)$ is $1 \%$ of the surface value, the euphotic zone averaged irradiance $I_{e}$ is,

$$
I_{e}=\left(I_{s} / Z_{s}\right) \int_{0}^{Z_{e}} e^{-k z} d z \cong 0.21 I_{s}
$$

Light limitation of phytoplankton growth has been modelled following Smith [1936],

$$
R_{L}=P / P_{\max }=\left(I / I_{k}\right)\left[1+\left(I / I_{k}\right)^{2}\right]^{-0.5}
$$

where $P$ is the gross photosynthesis rate, $P_{\max }$ the maximum photosynthesis rate, and $I_{k}$ the saturating irradiance [Talling, 1957], approximately $25 \mathrm{wm}^{-2}$ for these waters. The average light limitation may be computed by integrating $R_{L}$ over the euphotic zone depth, however a very good approximation is obtained by substituting $I_{e}$ for $I$ in (6).

There is a clear temperature effect on the growth rate of phytoplankton [Eppley, 1972] with the maximum rate of growth

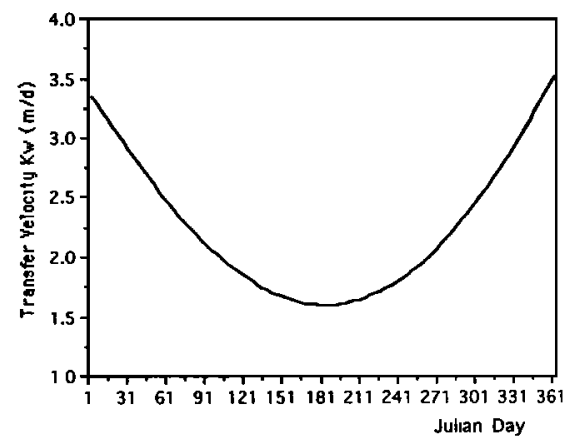

Figure 2. Predicted annual variation in transfer velocity at Cape Grim. 
roughly doubling every $10{ }^{\circ} \mathrm{C}$ increase in sea temperature. The dependence on temperature is given by,

$$
R_{T}=\left(\mu_{o} / \mu_{m}\right) e^{0.063 T}
$$

where $\mu_{0}$ is 0.84 day $^{-1}$ and $T$ is the temperature in degrees Celsius. For the maximum sea temperature in the study window $\left(14.6^{\circ} \mathrm{C}\right)$, the maximal growth rate $\mu_{m}$ is 2.1 day -1 . By comparison, for a winter sea temperature of $9.4^{\circ} \mathrm{C}$, growth rate is 1.5 day $^{-1}$ and $R_{T}$ is 0.72 .

\section{Atmospheric Phase}

An independent atmospheric phase estimate of the sea-air flux of DMS was derived by employing a conventional boundary layer box model to model the transformation of DMS in the atmosphere,

$$
\begin{aligned}
d[D M S] / d t & =F / H-K[O H][D M S] \\
& +E_{\nu}\left([D M S]_{t p}-[D M S]\right) / H
\end{aligned}
$$

where, $H$ is the boundary layer depth $(1000 \pm 300 \mathrm{~m}), F$ the seato-air flux of DMS, $E_{\mathrm{y}}$ the boundary layer-troposphere entrainment velocity $\left(0.35 \pm 0.2 \mathrm{~cm} \mathrm{~s}^{-1}\right)$, and [DMS] and $[D M S]_{t p}$ the concentrations in the boundary layer and lower troposphere, respectively. The uncertainty in $\mathrm{H}$ will cause a similar proportional uncertainty in the DMS flux. Variability in $\mathrm{E}_{\mathrm{v}}$ will be a minor effect in the spring-summer period simulated here, as the main sink for DMS during this time is photochemical reaction. Oxidation of DMS is assumed to occur solely by reaction with the hydroxyl $(\mathrm{OH})$ radical, which according to Langner and Rodhe [1991] is a reasonable assumption in clean marine air where $\mathrm{NO}_{x}$ levels are quite low. The $\mathrm{OH}$ concentrations and rate constant $K$ are derived from a photochemical model described in Bentley and Ayers [1991]. Using monthly average values for the DMS concentration as derived from Cape Grim measurements, and a value for [DMS $]_{t p}$ set to $10 \%$ of the boundary layer value [Berresheim et al., 1990], equation (9) may be solved for the monthly average flux $F$.

\section{Results and Discussion}

Chlorophyll pigment concentration for the Southern Ocean southwest of Cape Grim was derived from archival Coastal Zone Color Scanner (CZCS) data. The CZCS 1978-1986 monthly composite archive was processed for the $1000 \times 1000 \mathrm{~km}$ study window $41-51^{\circ} \mathrm{S}$ and $133.3-143.2^{\circ} \mathrm{E}$ and the results for spatially averaged chlorophyll-like pigment concentration are shown in Figure 1a and 1b. While there is no well-defined peak in the seasonal cycle, the minimum value in the northern section occurs over August to September while in the southern half the minimum occurs in June. In both sections variance is high throughout the year except during August and September. The monthly mean pigment concentration is in the range $0.2-0.3 \mathrm{mg}$

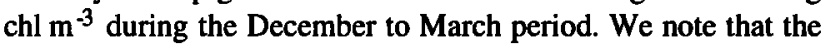

satellite-derived concentrations may underestimate the true mixed layer average chlorophyll when a subsurface chlorophyll maximum occurs [Smith, 1981].

While there is little data on the seasonal cycles of phytoplankton species in the Subantarctic Southern Ocean, it appears that diatoms are an important component of the total flora, especially further south. McTaggart and Burton [1992] report that coccolithophores form a significant portion of the total phytoplankton community north of the Antarctic Convergence $\left(53^{\circ} \mathrm{S}\right)$. Jacques et al. [1979] surveyed a transect in the Indian ocean sector of the Southern Ocean from $43^{\circ} \mathrm{S}$ to $62^{\circ} \mathrm{S}$ and suggested that diatoms became more dominant with increasing latitude. This may cause a meridional gradient in DMS production as coccolithophores are known to produce high levels of DMS, while diatoms are less significant producers [Keller et al., 1989].

Wind speed and temperature records collected at Cape Grim were statistically analysed and were used to compute the variation in DMS transfer velocity over a year and the results plotted in Figure 2. The transfer velocity varies from a maximum value of $3.4 \mathrm{md}^{-1}$ in January to a minimum in July of $1.6 \mathrm{md}^{-1}$. Erickson et al. [1990] computed global DMS transfer velocity based on global climate model generated wind and temperature fields. Their predictions for the Southern Ocean near Cape Grim are higher in winter $\left(6 \mathrm{md}^{-1}\right)$ than in summer $\left(3.6 \mathrm{md}^{-1}\right)$. Based on the local data on wind and air temperature the winter DMS flux given by Erickson et al. [1990] may be seriously overestimated.

The extended GMSK model was integrated forward in time from October through to mid -May, assuming that the oceanic mixed layer during spring-summer is $100 \mathrm{~m}$ deep. Model predictions are known to be very sensitive to the algal cell DMSP content. Assuming that the phytoplankton community is dominated by diatoms and coccolithophores, we choose a S(DMSP):N cell ratio of 0.3 [Gabric et al., 1993]. All other depth-dependent model parameters were rescaled to the $100 \mathrm{~m}$ mixed layer depth.

For a single realisation (see Figure 3), the model predicts that phytoplankton growth follows a cyclical pattern with period of about $\mathbf{4 0}$ days and a gradual decline in the peak with time due to light and temperature variation. DMS peaks lag the algal peaks by about 1-2 days and follow a similar decline. DMS levels remain high for at least $\mathbf{1 0}$ days after phytoplankton have been completely grazed. The mixed layer phytoplankton concentrations vary from almost 5000 to $800 \mathrm{mg} \mathrm{Nm}^{-2}$. Assuming a $\mathrm{C}: \mathrm{Ch}$ ratio of 50 (a notoriously variable parameter), this corresponds to chlorophyll concentrations in the range 6 to 1 $\mathrm{mg} \mathrm{m}^{-3}$. Dissolved DMS concentrations vary from 8 to $2 \mathrm{mg} \mathrm{S}$ (DMS) $\mathrm{m}^{-2}$, or 2.5 to $0.6 \mathrm{nM}$, which is similar to the range measured by Bates et al. [1987] in the North Pacific.

Given the large area of ocean that can affect DMS measurements made at Cape Grim and the likely presence of a number of algal species in different stages of growth, a single (a)

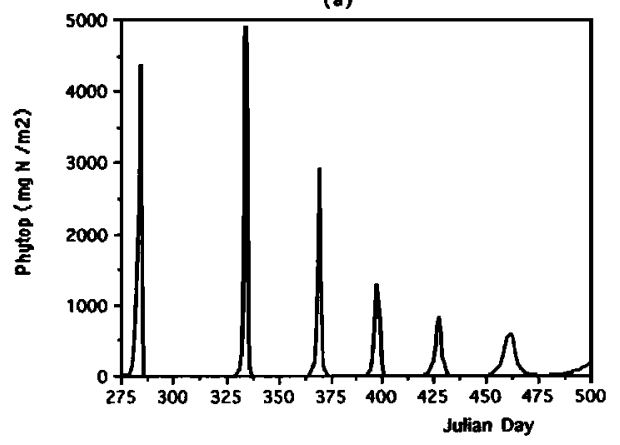

(b)

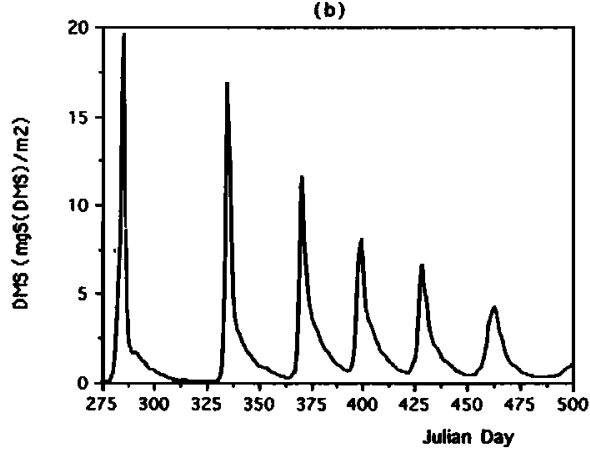

Figure 3. Predicted variation in (a) phytoplankton biomass and

(b) dissolved DMS. 


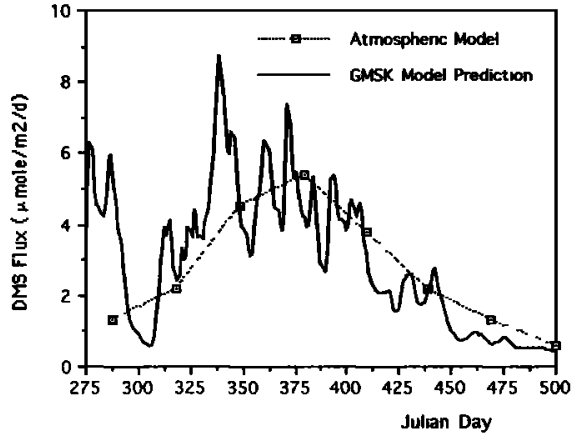

Figure 4. Independent marine and atmospheric model predictions for DMS sea-air flux.

model run is unlikely to be representative of the actual situation. In order to simulate time lags in the phytoplankton growth cycle that would be expected over the study region, several model runs were carried out, starting the integration one day apart from Julian day 265 to 285 . The results were then averaged to give the DMS flux profile shown in Figure 4. Accepting the limitation that the marine model assumes a biologically homogeneous ocean, the correspondence with the independently derived atmospheric model predictions is encouraging. The flux increases toward a maximum during summer and then decreases in autumn, reproducing well the general trend in atmospheric DMS concentration at Cape Grim.

It is interesting to note that the factor of five variation in DMS flux over the period of simulation is a result of both the range in transfer velocity (approximate factor of two) and the range in dissolved DMS (approximate factor of four). The coincidental synchronism in the timing of the maxima in transfer velocity and DMS production results in a flux maximum in the December -January period. The flux is very sensitive to changes in sea temperature which will affect both the physics $\left(\mathbf{k}_{\mathrm{w}}\right)$ and biology $(\mu)$ of the system. An increase in sea temperature (due to global warming) will increase the magnitude of both $k_{w}$ and $\mu$, however the net effect on DMS flux will depend on whether the seasonal cycle in sea temperature is also modified.

\section{References}

Andreae, M.O. and W.R. Barnard, The marine chemistry of dimethylsulfide, Mar. Chem., 14, 267-279, 1984.

Ayers, G.P., J.P. Ivey, and R.W. Gillett, Coherence between seasonal cycles of dimethylsulfide, methanesulphonate and sulphate in marine air, Nature, 349, 404-406, 1991.

Azam, F., T. Fenchel, J.S. Gray, L.A. Meyer-Reil and F. Thingstad, The ecological role of water-column microbes in the sea, Mar. Ecol. Prog. Ser. , 10, 257-263, 1983.

Baker, K.S. and R. Frouin, Relation between photosynthetically available radiation and total insolation at the ocean surface under clear skies, Limnol. Oceanogr., 32(6), 1370-1377, 1987.

Bates, T.S., J.D. Cline, R.H. Gammon, and S.R. Kelly-Hansen, Regional and seasonal variations in the flux of oceanic dimethylsulfide to the atmosphere, J. Geophys. Res., 92, C3, 2930-2938, 1987.

Bentley, S.T. and G.P. Ayers, An initial modelling perspective on local $\mathrm{OH}$ production in baseline air, in, Baseline 89, edited by S.R. Wilson and J.L. Gras, Bureau of Meteorology, Australia, pp. 30-37, 1991.

Berresheim, H., M.O. Andreae, G.P. Ayers, R.W. Gillet, J.T. Merrill, V.J. Harris, and W.L. Chameides, Airborne measurements of dimethylsulfide, sulfur dioxide and aerosol ions over the Southern Ocean south of Australia, J. Atmos. Chem., 10, 341-370, 1990.

Brock, T.D., Calculating solar radiation for ecological studies, Ecol. Model., 14, 1-19, 1981.

Charlson, J.E. Lovelock, M.O. Andreae and S.G. Warren, Oceanic phytoplankton, atmospheric sulphur, cloud albedo and climate, Nature, 326, 655-661, 1987.
Eppley, R.W., Temperature and phytoplankton growth in the sea, Fish Bull., 70, 1063-1085, 1972.

Erickson, D.J., S.J. Ghan, and J.E. Penner, Global ocean-to-atmosphere dimethyl sulfide flux, J. Geophys. Res., 95, D6, 7543-7552, 1990.

Fenchel, T., Marine plankton food chains, Ann. Rev. Ecol. Syst., 19, 1938, 1988.

Gabric, A.J., N. Murray , L. Stone, and M. Kohl, Modelling the production of dimethylsulfide during a phytoplankton bloom, $J$. Geophys. Res. , 98, C12, 22805-22816, 1993.

Iverson, R.L., F.L. Nearhoof and M.O. Andreae, Production of dimethylsulfonium and dimethylsulfide by phytoplankton in estuarine and coastal waters, Limnol. Oceanogr., 34(1), 53-67, 1989.

Jacques, G., C. Descolas-Gros, J.R. Grall and A. Sournia, Distribution du phytoplancton dans le partie antarctique de l'Ocean Indienne en fin d'ete, Int. rev. Res. Hydrobiol., 64, 609-628, 1979.

Jerlov, N.G., Marine Optics, Elsevier, 1976.

Jitts, H.R., A. Morel, and Y. Saijo, The relation of oceanic primary production to available photosynthetic irradiance, Aust. J. Mar. Freshwater Res., 27, 441-454, 1976.

Keller, M.D., W.K. Bellows and R.L. Guillard, Dimethyl Sulfide production in marine phytoplankton, in, Biogenic sulfur in the environment, edited by E.S. Saltzman and W.J. Cooper, pp. 167-182, American Chemical Society, Washington, D.C., 1989.

Kiene, R.P. and T.S. Bates, Biological removal of dimethylsulfide from seawater, Nature, 345, 702-705, 1990.

Koga, S. and H. Tanaka, Numerical study of the oxidation process of dimethylsulphide in the marine atmosphere, J. Atmos. Chem., 17, 203228, 1993.

Langner, J., and $\mathrm{H}$. Rodhe, A global three-dimensional model of the tropospheric sulfur cycle, J. Atmos. Chem., 13, 225-263, 1991.

Lawrence, M.G., An empirical analysis of the strength of the phytoplankton-dimethylsulfide-cloud-climate feedback cycle, $J$. Geophys. Res., 98, D11, 20663-20673, 1993.

Leck, C., U. Larsson, L.E. Bagander, S. Johansson, and S. Hajdu, DMS in the Baltic Sea - Annual variability in relation to biological activity, J. Geophys. Res., 95 (C3), 3353-3363, 1990.

Liss, P.S. and L Merlivat, Air-sea gas exchange rates: Introduction and synthesis, in, The role of air-sea exchange in geochemical cycling, edited by P. Buat-Menard, pp.113-127, Reidel, Hingham, MA, 1986.

Matrai. P.A., and M.D. Keller, Dimethylsulfide in a large-scale coccolithophore bloom in the Gulf of Maine, Contin. Shelf Res., 13 8/9, 831-843, 1993.

McTaggart, A.R., and H. Burton, Dimethylsulfide concentrations in the surface waters of the Australasian Antarctic and Subantarctic oceans during an austral summer, J. Geophys. Res., 97, 14407- 14412, 1992.

Nguyen, B.C., N. Mihalopoulos and S. Belviso, Seasonal variation of atmospheric dimethylsulphide at Amsterdam Island in the Southern Indian Ocean, J. Atmos. Chem., 11, 123-141, 1990.

Parsons, T.R., M. Takahashi and B. Hargrave, Biological Oceanographic Processes, 3rd Ed, 330 pp., Pergamon Press, 1984.

Pittock, A.B., Climate scenario development, in, Modelling Change in Environmental Systems, edited by A.J. Jakeman, M.B. Beck and M.J. McAleer, John Wiley, Chichester, 1993.

Platt, T., K.L. Denman, and A.D. Jassby, Modeling the productivity of phytoplankton, in, The Sea, Vol.6, edited by E.D. Goldberg, pp. 807 856, Wiley, New York, 1977.

Smith, E.L., Photosynthesis in relation to light and carbon dioxide, Proc. Nat. Acad. Science, Wash., 22, 504-511, 1936.

Smith, R.C., Remote sensing and the depth distribution of ocean chlorophyll, Mar. Ecol., 5, 359-361, 1981.

Talling, J.F., Photosynthetic characteristics of some freshwater plankton diatoms in relation to underwater radiation, New Phytol., 56, 29-50, 1957.

Turner, S.M., G. Malin , P.S. Liss , D.S. Harbour, and P.M. Holligan, The seasonal variation of dimethylsulfide and dimethylsulfoniopropionate concentrations in nearshore waters, Limnol. Oceanogr., 33(3), 364-375, 1988.

Wilson, S.R., and G.P. Ayers (Eds.) Baseline Atmospheric Program (Australia) 1988, Report produced jointly by Bureau of Meteorology and CSIRO Division of Atmospheric Research, 1990.

A. J. Gabric, Faculty of Environmental Sciences, Griffith University, Nathan, Queensland, Australia, 4111. (email: a.gabric@ens.gu.edu.a

G. P. Ayers, CSIRO Division of Atmospheric Research, Private Bag

1, Mordialloc, Victoria, Australia, 3195.(email: gpa@dar.csiro.au)

G. C. Sander, Faculty of Science and Technology, Griffith University, Nathan, Queensland, Australia, 4111.(email: g.sander@sct.gu.edu.au)

(Received : June 27, 1995; accepted: September 8, 1995) 